\title{
Hepatic damage associated with mineral oil deposits
}

\author{
R. W. BLEWITT, K. BRADBURY, M. J. GREENALL, AND HEATHER BURROW \\ From the Department of Pathology, University of Leeds, and The General Infirmary, Leeds
}

SUMMARY The case of a 33 year old male is reported. Hepatic inflammation and scarring were associated with deposits of mineral oil in portal triads. This is believed to be the first reported case of hepatic damage resulting from mineral oil accumulation. Possible sources of the oil are considered.

Accumulation in the liver, spleen, and lymph nodes of mineral oil derived from medicinal and other sources has been documented in North America (Boitnott and Margolis, 1966a, b; Liber and Rose, 1967; Boitnott and Margolis, 1970), although it has not been regarded as harmful (Boitnott and Margolis, 1966b).

This report describes, for the first time, appreciable hepatic damage in association with deposits of a lipid which was almost certainly mineral oil. That the oil might have caused the hepatic damage seems a distinct possibility.

\section{Case history}

A 33 year old engineer underwent the operation of highly selective vagotomy in 1975 for a peptic ulcer. For the previous nine years he had suffered from periodic dyspepsia, and a chronic duodenal ulcer had been demonstrated radiologically. During the course of the operation the liver was noted to be 'somewhat enlarged and irregular' and two biopsies were taken, together with an enlarged lymph node, from the porta hepatitis.

The operation was completed and the patient made a satisfactory recovery, apart from a transient episode of pleuritic chest pain occurring after discharge from hospital. Six months after the operation he was in good health with no further dyspepsia.

His only other recorded medical problem had been haemorrhoids, treated in 1961 by sclerosant injections consisting of $5 \%$ phenol in almond oil.

The patient smoked lightly and drank only in moderation. Previous drug therapy included a variety of preparations for the relief of dyspepsia, and one tablespoon of liquid paraffin taken as a laxative at bedtime 'possibly over a period of two months only', in the year before his gastric operation.

Received for publication 10 November 1976
He admitted, however, that his memory of previous medicaments was poor. Radiological investigations were limited to barium meals and chest radiographs and no oily contrast media had been administered.

\section{PATHOLOGICAL EXAMINATION}

\section{Liver}

The specimen consisted of a wedge of liver measuring $12 \times 5 \times 5 \mathrm{~mm}$. Sectioning revealed a pale area measuring $4 \times 2 \mathrm{~mm}$. A second wedge of liver measured $15 \times 10 \times 10 \mathrm{~mm}$ and contained multiple pale areas each about $1 \mathrm{~mm}$ in diameter.

Microscopically the pale area seen in the firstdescribed biopsy was a fibrotic portal triad containing large bile ducts and a blood vessel showing endarteritis obliterans (Fig. 1). There was oedema of the connective tissue, and scattered groups of cystic spaces were present at the periphery. Elsewhere in both biopsies portal triads contained cystic spaces, some with a histiocytic lining, and vacuolated histiocytes; they were infiltrated by chronic inflammatory cells with a few neutrophil leucocytes, and showed increased fibrous tissue and some bile ductule proliferation (Fig. 2). Mild fatty change was seen in the hepatic parenchyma.

A reticulin stain revealed slight irregularity of liver cell plates around portal triads, and an excess of reticulin within the triads.

In both liver biopsies the cystic spaces and vacuoles stained positively with oil red $\mathrm{O}$, faintly with sudan black B, but showed no staining with osmium tetroxide. In contrast, the parenchymal cells showing fatty change stained well with all three stains.

\section{Lymph node}

The specimen consisted of a nodule of tissue measuring $12 \times 5 \times 5 \mathrm{~mm}$.

Microscopically this lymph node contained lymphoid follicles with prominent germinal centres. 


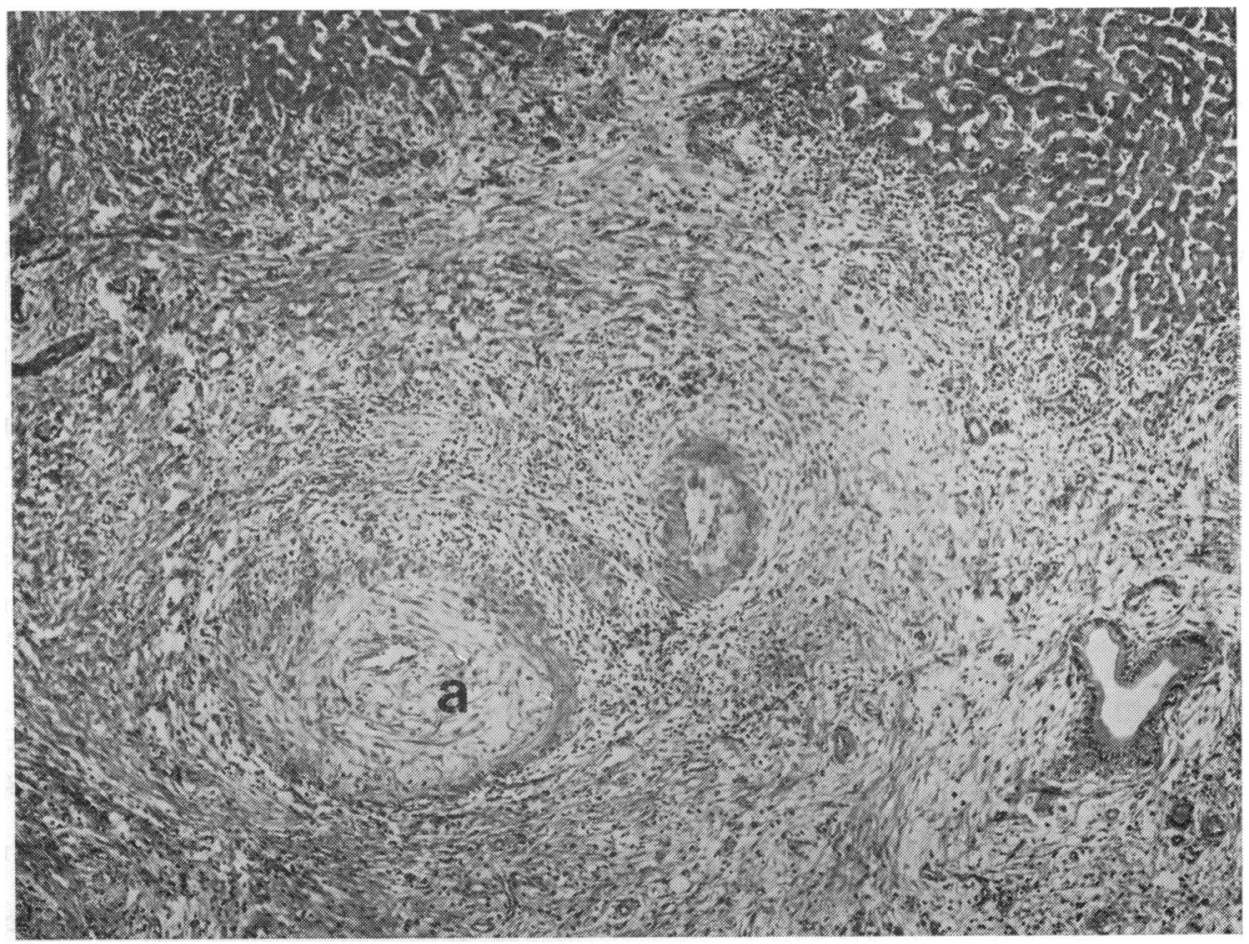

Fig. 2 Lipid spaces with a histiocytic lining (a) and vacuolated histiocytes (long arrows) in a portal triad.

There is chronic inflammation and proliferation of bile ductules (short arrows), $H$ and $E, \times 400$.

Fig. 1 Fibrotic portal triad with blood vessel showing endarteritis obliterans (a). $H$ and $E, \times 60$.

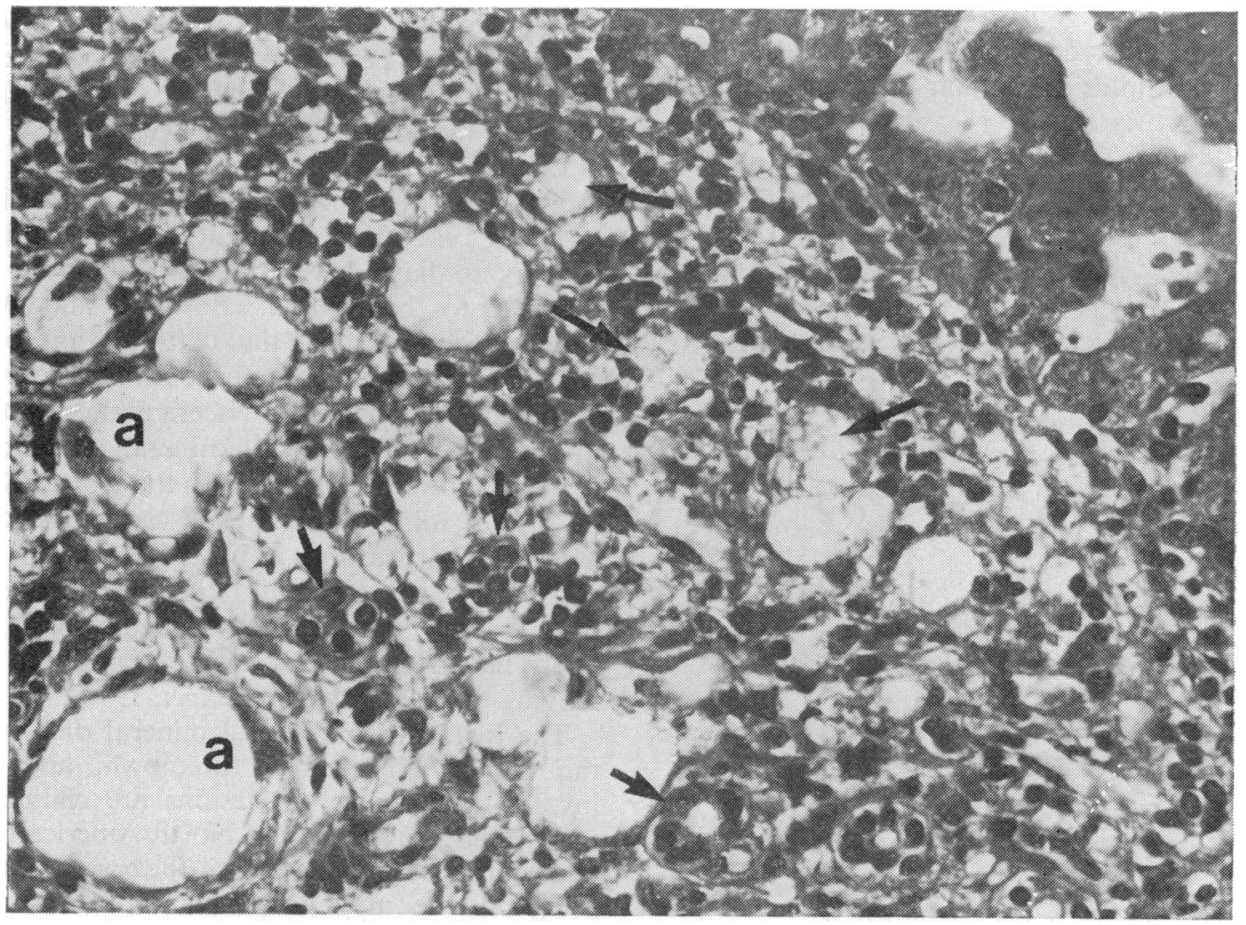


In the dilated medullary sinuses were seen plentiful histiocytes, as well as erythrocytes, lymphocytes, and scattered deposits of haemosiderin. Groups of cystic spaces, associated with many coarsely vacuolated histiocytes, were present in the cortex of the lymph node between follicles. Some of the cystic spaces were lined by histiocytes.

Lipid analysis of liver by thin-layer chromatography The method used was similar to that described by Boitnott and Margolis (1966a). Lipid was extracted by the Folch procedure (Folch et al., 1957) from $0 \cdot 1 \mathrm{~g}$ of the remaining unprocessed liver tissue. The lipid was spotted onto TLC plates of Kieselgur G (Merck) and developed in hexane. The plates were dried and lipids charred by sulphuric acid and heating.

On the developed plates the lipid extract from the patient's liver produced two spots with similar $\mathbf{R f}$ values to that of liquid paraffin (Fig. 3) and to those obtained with motor oil and engineering oil. Cholesterol, tripalmitan, lecithin, palmitic acid, castor oil, and almond oil failed to migrate from the origin in several tests. Lipid extracts of the liver and spleen from three necropsies failed to move from the origin.

\section{Discussion}

The morphology and staining characteristics of the hepatic portal lipids are similar to reported descrip-

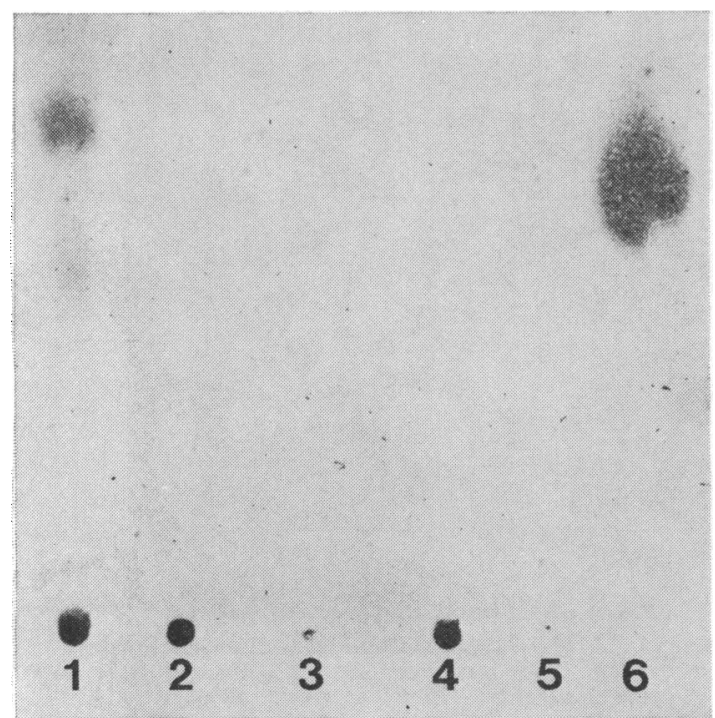

Fig. 3 Thin-layer chromatogram. The spots at the origin are: 1: lipid extract from the patient's liver, 2: cholesterol, 3: tripalmitan, 4: lecithin, 5: palmitic acid, 6: liquid paraffin. tions of mineral oil deposits (Boitnott and Margolis, 1966a, b; Boitnott and Margolis, 1970). These findings together with the thin-layer chromatography studies strongly suggest that the hepatic lipid deposits were saturated hydrocarbons, similar if not identical with liquid paraffin.

Hepatic lipid deposits resembling those found in our case were first described by Stryker (1941), and were mentioned by Volk et al. (1955), and Golberg and Saphir (1960). Boitnott and Margolis (1970) provided strong evidence that the lipid was mineral oil, using gas-liquid chromatography and mass spectrometry, and had previously concluded that the presence of such deposits in human tissue was not known to be harmful (Boitnott and Margolis, 1966b). In our patient the appearances of the liver both at operation and microscopically indicated that the mineral oil was associated with appreciable chronic inflammation and scarring in portal triads. There is no clinical or biochemical evidence of hepatic dysfunction at present, but it is conceivable that the portal fibrosis, should it continue, might lead eventually to portal hypertension.

The source of the hepatic lipid in the case reported here is of interest. The sclerosant solution used to treat the patient's haemorrhoids in 1961 consisted of phenol in almond oil which could have entered the portal venous system; however, this source has been discounted as almond oil contains unsaturated lipids and would be expected to stain with osmium tetroxide. Furthermore, almond oil failed to move from the origin in the thin-layer chromatograms.

Liquid paraffin is an obvious possibility as it is thought to be absorbed slightly from the intestine (Stryker, 1941). In our patient, liquid paraffin intake appears to have been modest, although it is not possible to be certain. Boitnott and Margolis (1966b) thought that the consumption of liquid paraffin was insufficient to account for the frequency of mineral oil deposits in viscera and drew attention to the large quantities of mineral oil used in the United States food industry. In the United Kingdom the use of mineral oil in foods is restricted by the Mineral Hydrocarbons in Food Regulations of 1966.

A further source of oil is possible in our patient who, having worked in the engineering industry, might have respired oily aerosols produced by fastmoving machinery parts (Lancet, 1970).

The incidence of visceral mineral oil deposits in the United Kingdom is unknown, and requires investigation, but these lesions are claimed to be increasing in frequency in North America (Boitnott and Margolis, 1966c). If this is the case in the United Kingdom we may encounter more examples of hepatic damage in association with mineral oil in the future. 
We should like to express our thanks to Professor D. Johnston for permission to describe this case, Dr M. F. Dixon and Dr Shirley Holt for advice, and $\mathrm{Mr} \mathrm{S}$. Toms for technical assistance.

\section{References}

Boitnott, J. K., and Margolis, S. (1966a). Mineral oil in human tissues. I. Detection of saturated hydrocarbons using thin-layer chromatography. Bulletin of the Johns Hopkins Hospital, 118, 402-413.

Boitnott, J. K., and Margolis, S. (1966b). Mineral oil in human tissues. II. Oil droplets in lymph nodes of the porta hepatis. Bulletin of the Johns Hopkins Hospital, 118, 414-422.

Boitnott, J. K., and Margolis, S. (1966c). The increasing incidence of mineral oil in human tissues. Federation Proceedings, 25, 200.

Boitnott, J. K., and Margolis, S. (1970). Saturated hydro- carbons in human tissues. III. Oil droplets in the liver and spleen. Johns Hopkins Medical Journal, 127, 65-78.

Folch, J., Lees, M., and Sloane Stanley, G. H. (1957). A simple inethod for the isolation and purification of total lipides from animal tissues. Journal of Biological Chemistry, 226, 497-509.

Goldberg, G. M., and Saphir, O. (1960). Lipidosis of the liver portal spaces. 1. A study of its relationship to the lymphatics of the liver. Archives of Pathology, 69, 586-593.

Lancet (Leading Article) (1970). Hazard of mineral-oil mist ? Lancet, 2, 967-968.

Liber, A. F., and Rose, H. G. (1967). Saturated hydrocarbons in follicular lipidosis of the spleen. Archives of Pathology, 83, 116-122.

Stryker, W. A. (1941). Absorption of liquid petrolatum ("mineral oil") from the intestine. A histologic and chemical study. Archives of Pathology, 31, 670-692.

Volk, B. W., Losner, S., Lewitan, A., and Nathanson, L. (1955). Diagnosis of lipoid pneumonia. American Journal of Surgery, 89, 158-165.

\section{The May 1977 Issue}

\section{THE MAY 1977 ISSUE CONTAINS THE FOLLOWING PAPERS}

Giardiasis: clinical and therapeutic aspects s. G. WRIGHT, A. M. TOMKINS, AND D. S. RIDLEY

Escherichia coli serotypes throughout the gastrointestinal tract of patients with intestinal disorders SOAD TABAQCHALI, ALISON HOWARD, C. H. TEOH-CHAN, K. A. BETTELHEIM, AND S. L. GORBACH

Role of intestinal microflora in colonic pseudoobstruction complicating jejunoileal bypass R. E. BARRY, A. W. CHOW, AND J. BILLESDON

Evidence for a transmissible factor in Crohn's disease B. J. DONNELLY, P. V. DELANEY, AND T. M. HEALY

Nodular lymphoid hyperplasia of the bowel in primary hypogammaglobulinaemia: study of in vivo and in vitro lymphocyte function A. D. B. WEBSTER, S. KENWRIGHT, J. BALLARD, M. SHINER, G. SLAVIN, A. J. LEVI, G. LOEWI, AND G. L. ASHERSON
Enterochromaffin cells in the duodenal mucosa of children with coeliac disease D. N. CHALLACOMBE AND K. ROBERTSON

Immunohistochemical identification of lysozyme in intestinal lesions in ulcerative colitis and Crohn's disease M. Klockars, S. ReITAMo, J. J. REITAMo, AND C. MÖLLER

Simple method for the preparation of single cell suspensions from normal and tumorous rat colonic mucosa V. PERRET, R. LEV, AND W. PIGMAN

\section{Progress report \\ Ultrasound and gastroenterology F. R. VICARY}

The British Society of Gastroenterology

Notes and activities

Copies are still available and may be obtained from the PUBLISHING MANAGER, BRITISH MEDICAL ASSOCIATION, TAVISTOCK SQUARE, LONDON WC1H $9 \mathrm{JR}$, price $£ 2 \cdot 75$, including postage 